\title{
Gender Difference in the Scholastic Achievement Test (SAT) among School Adolescents
}

\author{
Akpotor, Julie ${ }^{1, *} \&$ Egbule, Elizabeth ${ }^{2}$ \\ ${ }^{1}$ Department of Sociology/Psychology, Faculty of Social Sciences, Delta State University, Abraka, Nigeria \\ ${ }^{2}$ Department of Guidance \& Counselling, Faculty of Education, Delta State University, Abraka, Nigeria \\ *Correspondence: Department of Sociology/Psychology, Faculty of Social Sciences, Delta State University, Abraka, \\ Nigeria. E-mail: julieakpotor25@gmail.com
}

Received: February 14, 2019

Accepted: January 28, $2020 \quad$ Online Published: February 19, 2020

doi:10.5430/wje.v10n1p97

URL: https://doi.org/10.5430/wje.v10n1p97

\begin{abstract}
The paper examined gender difference in the Scholastic Achievement Test (SAT) among senior secondary school adolescents using the physical science of physics in three (3) separate papers. The paper attempted to ascertain whether gender difference accounts for the score differential observed in the Scholastic Achievement Test (SAT). The study adopted a field experiment and a sample size of 410 respondents consisting of 208 males and 202 females respectively. The correlation matrix of the three (3) papers was performed and the two (2) hypotheses were tested with the quintessential Multivariate Analysis of Variance (MANOVA) at 0.05 level of significance. The results showed that the gap between males and females widened from one paper to the other with males performing better than females in physics. It was therefore recommended that some motivational strategies should be adopted to stir up female adolescents in physics and other physical sciences as a way of enhancing their career prospects in science-related disciplines.
\end{abstract}

Keywords: gender, Scholastic Achievement Test, adolescents, secondary school

\section{Introduction}

The place of gender in intellectual engagement and achievement cannot be overemphasized and it is not a new phenomenon. It has been quite obvious that every academic activity, someone is expected to emerge the best or the last. It has been investigated and observed by most researchers that female students in secondary school seem to do better than males students in verbal skills and subjects such as English language and the arts while the males do better in non-verbal skills and science subjects. Some factors often suggested as responsible for this difference include students' personality traits, intelligence quotient, gregariousness, class attendance and students' relationship with teachers.

Hence many researchers (Dawson \& O'Connor, 1991; Dom \& Yi, 2018; van der Vleuten Jaspers, Maas, \& van der Lippe, 2016) have delved into the place of gender in students' choice of certain school subjects to determine whether performance is gender-based interestingly, many of these researchers have shown results in the direction of sex-aggregated education. In reality, what is known about gender difference comes from meta-analysis and some researchers have given reports on gender difference from investigations through meta-analysis (Batz-Barbarich, Tay, Kuykendall \& Cheung, 2018; Heintz, Kramm \& Ruch, 2017; Petersen, 2018; Nazareth, Huang, Voyer, \& Newcombe, 2019).

\subsection{Review of Related Literature}

The analysis of differences in performance in school subjects based on gender has shown that the direction of differences depends on the subject under investigation. It has been demonstrated that on the Scholastic Aptitude Test (SAT), men achieve generally higher performance than women (Amin, 2000). It has also been documented that at the college level, women tend to outperform men (Kimball, 1998). An argument for this trend in college according to Ramist (1990) and Daramola (1993) is that women tend to enrol more in courses of study whose grade distributions arc higher (the humanities and social sciences) than those courses for which the grade distributions tend to be lower (Engineering, mathematics and physical sciences). These courses are dominated by men. These differences are 
however not constant across tasks. For instance, the level of difference in an objective test may not be the same in an essay or practical test. Peterson and Livingstone (1992) studied group differences for the College Board English composition test in Cameroon. The test includes objective and essay samples. It was found that females' average was higher than males on both the multiple-choice and free-response portions of the test, although differences were smaller for the multiple-choice portion. Klein and Hodges (2001) also studied gender difference with the California Bar Examination which includes a multiple-choice test, 6 one-hour essay questions and 2 three hours written performance problems. The result of this study shows that males perform better on the multiple-choice test but females performed better on both the essay test and written performance test. The observation that females performed better on free-response tasks is not an uncommon assumption. Sincoff and Sternberg (1988) in a paper on verbal fluency differences in school-age children reported that girls especially those above ages 11 tend to score higher than boys on verbal fluency tasks.

Daramola (1993) undertook a study on the influence of schools and sex difference of students on the knowledge of basic physics possessed by students in Kwara State. Data concerning the students who participated in the study were collected by administering a Basic Physics Test to them. The results of the study revealed that the urban students obtained a mean score which was significantly greater than that obtained by rural students. However, the male and female students mean scores on the Basic Physics Test were not significantly different. In another study, Bolger and Kellagha (1990) examined the method of measurement and gender difference in scholastic achievement. They observed in their finding that male students are more likely to perform better than their female counterparts in multiple-choice tests than in free-response tests.

Studies on the relationship between the teacher and the student revealed that it is the most important factor in teaching success (Echezona, 1992). The teacher's personality and the learning characteristics of the adolescents are somewhat inseparable lines of study for the secondary school teacher who seeks improvement.

\subsection{Statement of the Problem}

The problem under investigation is to determine the differences in the three processes of physics assessment (practical Essay and multiple-choice tests) in terms of their different levels of difficulty. There are differences in performance according to gender across different tasks. The review of related literature presented above guided the formulation of the following hypotheses

\subsection{Hypotheses}

1. Here is no significant difference between males and females performance in the physics assessment test.

2. The difference in performance in physics between male and female candidates does not significantly vary from one test to another.

\section{Methods}

\subsection{Method of Data Collection}

An experimental field method was employed in determining differences in the achievement of males and females in three (3) separate scholastic achievement tests (SAT) in Physics for Psychological Counselling

\subsection{Instrument of Data Collection}

Paper I: Paper one is practical and made up of two questions. Students are required to answer any of the questions. Each question has psychomotor, cognitive and affective domains and carries a total of 25 marks. The paper 1 maximum score is 50 marks. The assessments on the psychomotor and affective domains were assessed on the spot while the cognitive aspect was done by what the students wrote.

Paper 2: Paper 2 consists of two sections. Section A had questions which measure knowledge, comprehension and application of physics concepts. It is made up of six questions that carry a total score of 30 marks. Section B had questions which measure analysis, synthesis and evaluation. Three questions were asked. Section B has a total of 30 marks. Students were required to answer the entire questions in paper 2. Paper 2 has a total of 60 marks.

Paper 3: Consists of 50 multiple-choice tests. Each question has one mark, making a total of 50 marks.

\subsection{Sampling and Sampling Size}

The sample consisted of 410 physics students from Ika South, Ika East, Ndokwa West, and Ukwani Local Government Areas of Delta State. 
Table 1. Distribution of Students by School and by Sex

\begin{tabular}{llll}
\hline School & Male & Female & Total \\
\hline Gbenoba Grammar School, Agbor & 52 & - & 52 \\
Mary Mount College, Owa & - & 65 & 65 \\
Ebologu Grammar Schoo, Utagba-Uno & 22 & 13 & 35 \\
Utaba-Ogbe Grammar School, Utagba-Ogbe & 40 & 35 & 75 \\
I.C.E. Umutu & 15 & 11 & 26 \\
Mixed Secondary School, Umuaja & 42 & 38 & 80 \\
St. Charles Abavo & 37 & - & 37 \\
Baptists Girls High School, Agbor & - & 40 & 40 \\
& 208 & 202 & 410 \\
\hline
\end{tabular}

\subsection{Method of Data Analysis}

To determine the reliability of the examination, the Cronbach's reliability coefficient alpha $(\alpha)$ was calculated for each of the three papers and the entire examination consisting of all the three papers, using the formula:
$\operatorname{Alpha}(\mathrm{a})=\frac{(N) \operatorname{Coy} / \text { Var }}{1+(N-1) \operatorname{cov} / v a r}$
Where $\mathrm{N}=$ Number of items on the test.
Coy. = average covariance between the items
Var. = average variance of the items.

To examine the differential performance of students on the $1+(\mathrm{N}-1)$ three papers, the total for each of the three papers (1.2 and 3) was computed by adding the marks for each of those papers and converting the total to a percentage. The means of papers 1, 2 and 3 were calculated.

To test the two hypotheses, a repeated measure multivariate analysis of Variance was computed with sex constituting the between-subjects factor while the papers (papers 1,2 and 3) were the within-subjects factor at $=0.05$.

The Cronbach reliability coefficient alpha was calculated and found to be 0.85 for paper 1, 0.59 for paper 2, 0.69 for paper 3 and 0.88 for the three papers taken as one scale. When interpreted as the squared correction between the scores a person obtained on a particular scale and the score he would have obtained if questioned on all possible items, then we see that the Cronbach alpha coefficients calculated above are quite high. These three papers of the assessment can be considered to be family reliable. The mean and standard deviation by paper and by sex are presented in Table 2 .

Table 2. Distribution of Means by Paper or by Sex

\begin{tabular}{lllllll}
\hline & \multicolumn{2}{c}{ Population } & \multicolumn{2}{c}{ Male } & \multicolumn{2}{c}{ Female } \\
\hline Paper & Means & SD & Means & SD & Means & SD \\
\hline 1 & 50.9 & 17.7 & 52.3 & 17.5 & 46.7 & 17.1 \\
2 & 60.6 & 19.5 & 62.5 & 18.6 & 55.0 & 27.1 \\
3 & 55.9 & 18.0 & 58.1 & 29.6 & 49.6 & 17.1 \\
\hline
\end{tabular}

\section{Results}

Hypothesis 1: There is no significant difference between males and females performance in the physics assessment test.

The result of hypothesis 1 is presented in table 3 .

Table 3. Test of Significant Difference between Subjects (Sex) Effect.

\begin{tabular}{llllll}
\hline & $S S$ & $d f$ & $M S$ & $F$ & Sig. $F$ \\
\hline Within Cells & 468300.6 & 408 & 857.69 & & \\
Constant & 1426869.9 & 1 & 166361 & 166361 & 0.000 \\
Sex & 15820.4 & 1 & 15820.4 & 18.45 & 0.000 \\
\hline
\end{tabular}


An examination of Table 3 shows that males consistently performed better than females on all three papers requiring different types of tasks. Hypothesis one is therefore rejected, which implies that a significant difference exists between males and females performance in the physics assessment test.

Hypothesis 2: The difference in performance in physics between male and female candidates does not significantly vary from one test to another.

The result of hypothesis 2 is presented in Table 4.

Table 4. Two-way ANOVA for Testing Interaction Effects

\begin{tabular}{llllll}
\hline Source of Variation & SS & DF & MS & F & Sig. F \\
\hline Within Cells & 72271.16 & 1092 & 66.18 & & \\
Paper & 17614.14 & 2 & 8807.1 & 133.1 & 0.000 \\
Sex by Paper Interaction & 468.38 & 2 & 234.1 & 3.5 & 0.029 \\
\hline
\end{tabular}

The interaction terms shown in table 4 is significant and hypothesis two is therefore rejected. This implies that the difference between means for males and females vary from paper to paper.

\section{Discussion}

This study examined gender difference in the Scholastic Achievement Test (SAT) among school adolescents. The objective of the paper is to ascertain whether differences observed in the performance of students in SAT is due to their gender difference. The result of the analysis conducted showed that a significant difference exists between males and females performance in the physics assessment test. This implies that the difference observed in the performance of the students is accounted for by their gender difference. This finding confirms the result of several studies (Amin, 2000; Kimball, 1998; Peterson \& Livingstone, 1992). These studies found significant gender differences in various subject areas.

The current study also found out that the difference between means for males and females vary from paper to paper. This finding has shown that the differences observed in the performance of male and female students can be moderated by the type of paper used. This finding is in line with the observation of Bolger and Kellaghan (1990), who found out that the performance of male and female students can vary as a function of the method of measurement used.

\section{Conclusion and Recommendations}

The gap between male and female performance widened from paper one through three, perhaps for the reason that applied to mathematics being inherent in physics (Amin, 2000). The results showed that the candidates found paper one more difficult while paper two was less difficult. Although the males generally performed better than the females, the difference between their performances was not constant across the different tasks. In other words, interaction effects were found significant.

Based on the above findings and conclusion, it is recommended that further motivational strategies and instructional techniques should be employed in enhancing the performance of the female folks in Physics and other physical sciences for their career uplift.

\section{References}

Amin, E. A. (2000). Tender differences in performance in the Cameroon Advanced Level Mathematics Examination. Journal of Nigerian Educational Research Association, 14(20), 41-49.

Bolger, N., \& Kellagha, T. (1990). Method of measurement and gender differences in scholastic achievement. Journal of Educational Measurement, 27(2), 165-174. https://doi.org/10.1111/j.1745-3984.1990.tb00740.x

Daramola, S. O. (1993). The influence of Location and Sex Difference on the knowledge of Basic Physics possessed by Entering Form IV students in Kwara State Secondary School. Journal of the Science Teachers Association of Nigeria, 21(2), 126-132.

Echezona, A. A. (1992). Human Relations: A Missing Link in Teacher Education and Teacher's function. Unpublished Manuscript Enugu State School Service. 
Iyewarun, S. A. (1993). A study of the relationship between Teachers' behaviour and students Achievement. Journal of the Science Teachers Association of Nigerian, 21(21), 117-125.

Jones, J. (1990). Outcomes of Girls' Schooling: Unravelling some social differences. Australian Journal of Education, 34(2), 153-167. https://doi.org/10.1177/000494419003400206

Kimball, M. M. (1998). A new perspective on women's Mathematics Achievements Psychological Bulletin, 105, 198-214. https://doi.org/10.1037/0033-2909.105.2.198

Klein, K. J. K., \& Hodges, S. D. (2001). Gender differences, motivation, and empathic accuracy: When it pays to understand. $P S P B, 27(6), 720-730$. https://doi.org/10.1177/0146167201276007

Medly, D. M. (1997). Teacher's competence and teachers Effectiveness. American Association of Colleges for Teachers Education.

Peterson, N., \& Livingstone, S. L. (1992). English Composition Test with Essay: A descriptive study of the relationship between Essays and Objective scores by Ethnic Group and sex. Statistical Report, 82-96.

Ramist, L. (1990). Predictive validity of ATP Tests. The College Board Technical Handbook for the Scholastic Aptitude Tests and Achievement Tests. College Entrance Examinations Boards.

Rouk, V. (1991). Separate Studies show similar Result of Teacher's Effectiveness. Education Research and Development Report, 2, 6-10.

Sincoff, J. B., \& Sternberg, R. J. (1988). Development of verbal fluency abilities and strategies in elementary-school-age children. Developmental Psychology, 24, 646-653. https://doi.org/10.1037/0012-1649.24.5.646

Dawson, C., \& O'Connor, P. (1991). Gender differences when choosing school subjects: Parental push and career pull, some tentative hypotheses. Research in Science Education, 21, 55-64. https://doi.org/10.1007/BF02360457

Van der Vleuten, M., Jaspers, E., Maas, I., \& Van der Lippe, T. (2016). Boys' and girls' educational choices in secondary education. The role of gender ideology, Educational Studies, 42(2), 181-200. https://doi.org/10.1080/03055698.2016.1160821

Dom, V., \& Yi, G. (2018). Gender and subject choice: an empirical study on undergraduate students' majors in Phnom Penh. Asian Journal of Social Sciences \& Humanities, 7(1), 40-47.

Batz-Barbarich, C., Tay, L., Kuykendall, L., \& Cheung, H. K. (2018). A meta-analysis of gender differences in subjective well-being: Estimating effect sizes and associations with gender inequality. Psychological Science, 29(9), 1491-1503. https://doi.org/10.1177/0956797618774796

Petersen, J. (2018). Gender Difference in Verbal Performance: A Meta-analysis of United States State Performance Assessments. Educ Psychol Rev, 30, 1269-1281. https://doi.org/10.1007/s10648-018-9450-x

Nazareth, A., Huang, X., Voyer, D., \& Newcombe, N. (2019). A meta-analysis of sex differences in human navigation skills. Psychonomic Bulletin \& Review, 26, 1503-1528. https://doi.org/10.3758/s13423-019-01633-6

Heintz, S., Kramm, C., \& Ruch, W. (2017). A meta-analysis of gender differences in character strengths and age, nation, and measure as moderators. The Journal of Positive Psychology, 14(1), 141-10. https://doi.org/10.1080/17439760.2017.1414297 